\title{
Immune Profile of Broilers between Hatch and 9 Days of Age Fed Diets with Different Betaine and Fibre Concentrations
}

\author{
Tiago T. dos Santos ${ }^{1 *}$, Suelen Cristina Soares Baal ${ }^{2}$, Sophie A. Lee ${ }^{1}$, Mike Bedford ${ }^{1}$, Celso Fávaro $\mathrm{Jr}^{3}$ and Ana Vitória \\ Fischer da Silva ${ }^{4}$ \\ ${ }^{I}$ AB Vista, Marlborough, United Kingdom, SN8 4AN \\ ${ }^{2}$ Graduate student, Universidade Federal do Paraná, Curitiba, Brazil, 81531-900 \\ ${ }^{3}$ Imunova Análises Biológicas LTDA, Curitiba, Brazil, 81690-100 \\ ${ }^{4}$ Department of Physiology, Universidade Federal do Paraná, Curitiba, Brazil, 81531-900 \\ *Corresponding author's Email: tiago.santos@abvista.com; ORCID: 0000-0002-6504-8086
}

Received: 29 Apri. 2020

Accepted: 03 June 2020

\begin{abstract}
An experiment was designed to determine the immune profile of broiler chickens between hatch and 9 days of age when fed diets with different fibre and betaine concentrations. A total of 240 day-old Cobb 500 male chickens were allocated to 16 cages with 15 chickens each. Treatments were arranged in a $2 \times 4$ factorial design, with 2 replicate cages per treatment. Treatments consisted of two feed formulations (low and high fibre diets) and four levels of betaine ( $0,1,3 \mathrm{or} 5 \mathrm{~kg} / \mathrm{tonne}$ ). Before the start of trial (hatch), 10 broilers were weighed and blood samples were collected by cardiac puncture, then euthanised by cervical dislocation and jejunal samples collected for the determination of gene expression of claudin 1 , claudin 5, occludin and interleukin 2 by PCR. Mononuclear cells populations in the blood samples were determined by flow cytometry. On days 4 and 9, five birds/cage (10 birds/treatment) were selected, euthanised and samples taken as per the start of hatch. Gene expression of claudin 1, claudin 5 and occludin was reduced between 4 and 9 days, independent of the group tested, while interleukin tended to increase between hatch and 4 days and decreased thereafter. Betaine inclusion reduced claudin 5 and occludin gene expression and increased CD8- CD28+ and CD8+ CD28+, suggesting it may aid in accelerating maturation of both the gastrointestinal tract and immune system for broilers in the early days post-hatch.
\end{abstract}

Key words: Betaine; Fibre; Gene expression; Maturation; Immune response

\section{INTRODUCTION}

The genetic selection imposed on broilers for improving weight gain and feed conversion ratio has reduced its immunocompetence and as a result, increased the disease susceptibility (Bridle et al., 2006). The generation of an unnecessary immune response represents a significant expense of energy and nutrients that could be targeted for other processes such as body weight gain. On other hand, failure to generate an immune response when required, is even more detrimental due to the morbidity and mortality it may cause. The immune system not only react to pathogenic challenges but also support the nervous system maintaining animal homeostasis (Tada, 1997).

At hatch, broilers do not have a fully developed immune system (Kogut, 2017). Both cellular and humoral immune systems develop during the first few days post hatch, including the development of the bursa of Fabricius and the thymus (Dibner et al., 1998) that increase proportionally more than other organs at early ages, receding as the animal gets older (Cazaban et al., 2015).

The gastrointestinal tract is not fully developed at hatch (Uni et al., 2003). The association in development of these two systems is linked because the development of the immune system depends on the availability of nutrients and energy absorbed via the gastrointestinal tract. Moreover, the gut functions as a sensory organ for the development of the immune system (Furness et al., 2013). Impaired nutrient absorption can influence the initial development of the immune system, compromising immunocompetence of the animal (Dibner et al., 1998). At the same time, maintenance of the immune status in the gastrointestinal tract has a high cost for the animal (Kogut et al., 2017). 
At hatch, gastrointestinal enterocytes are not tightly linked to each other, allowing the passage of large molecules via paracelullar routes directly into the interstitial spaces (Karcher and Applegate, 2008). Opening of paracellular passages is a route used by pathogenic bacteria and viruses while other bacteria actually increase rigidity of these junctions thereby reducing permeability (Sommer and Backhed, 2013). Gut-associated lymphoid tissues are agglomeration of immune cells which protect the body against the passage of microbiota from the gastrointestinal tract to other organs that are more concentrated in the hindgut and especially the ceca where the microbiota population is highest (Yegani and Korver, 2008).

The gut microbiota changes as soon as the animal starts to eat (Ballou et al., 2016). The composition of the feed influences the immune status of the animal and the species of bacteria that colonize the tract (Oakley and Kogut, 2016). The diet also influences the osmolarity of the intestines, with hyperosmolarity often stimulating inflammatory responses (Schwartz et al., 2009). Thus, the composition of the feed can influence the immune status of broilers. High fibre diets have been shown to increase the digesta transit time and stimulate bacteria growth due to a reduction in nutrient digestibility (Adeola et al., 2016) and also increase gut fermentation and possibly increase the inflammatory status of the digestive tract (Celi et al., 2017). On the other hand, fibre fermentation in the lower gut stimulates volatile fat acid such as butyrate, a trophic substance that stimulates villus growth (Rahmatnejad and Saki, 2016), increases gap junction protein expression, reduces inflammatory responses and endogenous losses during a coccidial challenge (Adedokun et al., 2012), lowers the presence of pathogenic bacteria in internal organs and improves animal performance (Rezaei et al., 2011).

Betaine is an osmoprotectant and is recognised as a chemical chaperone preventing protein denaturation and thus maintaining cell activity in hyperosmotic situations (Schwahn et al., 2003). Birds fed betaine have been shown to have reduced inflammatory responses when subsequently exposed to a coccidial challenge and maintain higher water flow and villus size (Kettunen et al., 2001), but similar effects were not observed when the betaine was offered at the same time as the coccidial challenge (Matthews and Southern, 2000).

The objective of the present study was thus to evaluate the proportion of circulating immune cells, and the tight protein and interleukin 2 gene expression in broilers at hatch, 4 and 9 days of age when fed diets with different levels of fibre and inclusion rates of betaine.

\section{MATERIALS AND METHODS}

\section{Ethical approval}

The study design was reviewed and approved by the Animal Use Ethics Committee of the Agricultural Science Campus of the Universidade Federal do Paraná (Protocol number 002/2015).

\section{Animals, diets and experimental design}

Two hundred and forty day-old male Cobb 500 broilers were sourced specifically for the experiment and housed in 16 stainless steel cages with 15 birds/cage. A further 10 birds were included for sampling at hatch, for measurement of the parameters of interest at the outset of the experiment. Room temperature was controlled with electric heaters to meet the breeder recommendations for the age of the bird (Cobb-Vantress Inc., 2015). Cage dimensions were $0.90 \mathrm{~m} \times 0.40 \mathrm{~m}$, and $0.30 \mathrm{~m}$ height. Birds had ad libitum access to water and feed. Treatments were designed in a $2 \times$ 4 factorial arrangement with two levels of fibre concentration (low and high) and four inclusion rates of betaine ( $0,1,3$ and $5 \mathrm{~kg}$ betaine/tonne of feed). Experimental diets were based on corn, soybean and rice bran as previously described (Santos et al., 2019) with Betaine (Vistabet ${ }^{\circledR}$ 96, AB Vista - Marlborough, United Kingdom) included at the targeted rate for each treatment by replacing the relevant weight of washed sand (Table 1).

\section{Sample collection}

At hatch, 10 birds that were not assigned to any treatment were weighed and separated for initial sampling. Blood was collected by cardiac puncture. Birds were then euthanized by cervical dislocation. The intestine was collected from the cardiac junction to the cloaca. One jejunal sample, defined as the section between the duodenal loop and $1 \mathrm{~cm}$ distal of the Meckel`s diverticulum (Teirlynck et al., 2009), was taken from each bird. At 4 and 9 days of age, 10 birds per treatment were separated and the same collection process was followed for blood and jejunum collection. 


\section{Flow cytometry analysis}

Approximately $2 \mathrm{~mL}$ of blood was collected into a heparin treated vacutainer tube. Initially, the mononuclear cells in the blood were isolated using Histopaque-1077 (Sigma Aldrich, St. Louis, USA), as described by Fair et al. (2008). Briefly, blood samples were centrifuged at $400 \mathrm{x} \mathrm{g}$ for $30 \mathrm{~min}$ after dilution with Phosphate-Buffered Saline (PBS) and Histopaque-1077, and white cells then collected as the layer above the erythrocytes. The white cells were then washed with PBS and centrifuged at $400 \mathrm{x}$ g for $7 \mathrm{~min}$. Samples were fixed with $1 \%$ paraformaldehyde and counted using a Neubauer counting chamber.

Once the cell concentration in the blood was determined, flow cytometry was performed as reported by

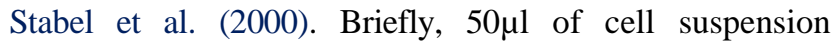
(equivalent to $10^{6}$ mononuclear cells) was incubated for 30 min at $37{ }^{\circ} \mathrm{C}$ with specific primary antibodies and fixed in paraformaldehyde for $30 \mathrm{~min}$ at $4{ }^{\circ} \mathrm{C}$. This process was repeated for the secondary antibody. Monoclonal antibodies to the specific subset of cells were supplied by Southern Biotechnology. "CD4” specificity for T helper lymphocytes; "CD8 $\beta$ " specificity for T cytotoxic lymphocytes; "CD28" specificity for memory T lymphocytes; "Mo" specificity for monocytes; "MHCII" specificity for antigen-presenting cells and "TCR $\alpha \beta \mathrm{V} \beta 1$ " specificity for T lymphocytes were prepared.

Reading was performed within $2 \mathrm{~h}$ of staining on a FACSCalibur flow cytometer (Becton Dickinson, United Kingdom), as reported by Beirão et al. (2012). Green fluorescence was detected on the FL1 channel (530/30 nm), and orange fluorescence was detected on the FL2 channel $(585 / 42 \mathrm{~nm})$. Cells were analysed at up to 10,000 events in the lymphocyte gate and data were analysed with FlowJo software (TreeStar Inc., United States).

\section{Gene expression}

Jejunal samples were immediately put in dry ice after sampling and stored at $-80{ }^{\circ} \mathrm{C}$. A $5 \mathrm{~mm}^{2}$ section of each sample was collected and processed as described by Adedokun et al. (2012). RNA extraction was proceed using RNAzol $^{\circledR}$ RT kit as per the manufacturer's protocol (Molecular Research Center Inc., Cincinnati, OH, USA). The RNA pellet was dissolved in nuclease-free water (Omnipure, EMD Chemicals Inc., Gibbstown, NJ) and its concentration determined using a 260/280 nm nanodrop spectrophotometer (Fisher Scientific, St. Louis, MO) and extracted RNA stored at $-80^{\circ} \mathrm{C}$ (Beirão et al., 2012).

Primers were designed for real-time PCR with the Oligo Analyzer 3.1 tool from Integrated DNA Technologies for the (complementary DNA) cDNA sequence obtained from the NCBI database. Genes evaluated in this study were glyceraldehyde-3-phosphate dehydrogenase (GAPDH) which served as the housekeeping gene, claudin 1 and 5, occludin and interleukin 2. A list of the primers used in the present study is reported in table 2 .

PCR analysis was performed as described by Bustin et al. (2009). Complementary DNA was synthesized from $1 \mu \mathrm{g}$ of total RNA using iScript Select cDNA Synthesis kit $\left(\right.$ BioRad) with Oligo $(\mathrm{dT})_{20}$ primer mix and GSP enhancer solution. The synthesis reaction was follows: $25{ }^{\circ} \mathrm{C}$ for 5 $\min , 42{ }^{\circ} \mathrm{C}$ for $1 \mathrm{~h}$, and $70{ }^{\circ} \mathrm{C}$ for $15 \mathrm{~min}$. The reaction for PCR were carried out on a RotorGene Real-Time PCR System (Quiagen Inc., Thousand Oaks, CA) in an EvaGreen fluorescent system. The following PCR conditions were used: $95{ }^{\circ} \mathrm{C}$ for $10 \mathrm{~min}$, followed by 40 cycles of $60{ }^{\circ} \mathrm{C}$ for $10 \mathrm{sec}$ and $95{ }^{\circ} \mathrm{C}$ for $10 \mathrm{sec}$. All samples were processed in triplicate and expressed relative to the house-keeping gene. For the analysis of gene expression at different ages, the expression was calculated based on the average expression of the target gene and housekeeping gene as reported by Pfaffi (2001) using the results from the low fibre diet without betaine inclusion as the reference.

\section{Statistical analysis}

Data was log-transformed prior to analysis as described by Beirão et al. (2012). Data were subjected to ANOVA using the GLM model for completely randomised design procedure of JMP Pro (SAS Institute Inc., Cary, NC, USA). Treatment means at hatch, 4 and 9 days of age were separated by Tukey`s Significant Difference test. Results at 4 and 9 days of age were also analysed using a two-way interaction considering fibre and betaine inclusion levels for the gene expression data and inclusion of a third factor, age, to generate the three-way interaction for the leukocyte population. A three-way interaction for gene expression was not considered as the samples were not collected from the same animals. Each animal served as the experimental unit. Statistical significance was accepted at $\mathrm{p}<0.05$. 
Table 1. Ingredients and chemical composition of experimental diets $\left(\mathrm{g} / \mathrm{kg}\right.$, as-fed basis). ${ }^{1}$

\begin{tabular}{|c|c|c|}
\hline Ingredients & $\begin{array}{c}\text { Low fibre } \\
\text { diet }\end{array}$ & $\begin{array}{c}\text { High fibre } \\
\text { diet }\end{array}$ \\
\hline Corn $\left(8 \% \mathrm{CP}^{2}\right)$ & 533.60 & 463.80 \\
\hline Rice bran $\left(12.5 \% \mathrm{CP}^{2}\right)$ & - & 70.00 \\
\hline Soybean oil & 35.00 & 43.50 \\
\hline Soybean meal $\left(46 \% \mathrm{CP}^{2}\right)$ & 385.00 & 376.50 \\
\hline Limestone & 10.60 & 10.90 \\
\hline Dicalcium phosphate & 18.00 & 17.50 \\
\hline Salt & 4.60 & 4.60 \\
\hline Vitamin/Mineral premix ${ }^{3}$ & 2.00 & 2.00 \\
\hline Lysine $\mathrm{HCl}$ & 2.05 & 2.05 \\
\hline DL Methionine & 3.25 & 3.25 \\
\hline L- Threonine & 0.65 & 0.70 \\
\hline Washed sand & 5.00 & 5.00 \\
\hline Choline Cloride & 0.25 & 0.20 \\
\hline \multicolumn{3}{|l|}{ Chemical composition } \\
\hline Crude protein & 220 & 220 \\
\hline Metabolizable energy, $\mathrm{kcal} / \mathrm{kg}$ & 3000 & 3000 \\
\hline Crude fibre & 29.50 & 43.50 \\
\hline Sol. Arabinoxylane & 0.53 & 0.60 \\
\hline Insol. Arabinoxylanse & 19.21 & 21.81 \\
\hline Sol NSP ${ }^{4}$ & 19.88 & 19.30 \\
\hline Insol NSP ${ }^{4}$ & 89.48 & 93.74 \\
\hline Ether extract & 60.00 & 77.00 \\
\hline Ash & 34.00 & 39.00 \\
\hline Calcium & 9.50 & 9.50 \\
\hline Phosphorous & 6.80 & 7.60 \\
\hline Available Phosphorous & 4.50 & 4.50 \\
\hline Sodium & 2.00 & 2.00 \\
\hline Digestible Lysine & 12.50 & 12.50 \\
\hline Digestible Methionine+Cysteine & 9.10 & 9.10 \\
\hline Digestible Threonine & 8.10 & 8.10 \\
\hline \multicolumn{3}{|c|}{$\begin{array}{l}{ }^{1} \text { Betaine included at the expense of inert. }{ }^{2} \text { Crude Protein. }{ }^{3} \text { Supplied per } \\
\text { kilogram diet: iron (Ferrous Sulphate), } 60 \mathrm{mg} \text {; manganese (Manganese } \\
\text { Sulphate and Manganese Oxide), } 120 \mathrm{mg} \text {; zinc (Zinc Oxide), } 100 \mathrm{mg} \text {; } \\
\text { iodine (Calcium Iodate), } 1 \mathrm{mg} \text {; copper (Copper Sulphate), } 8 \mathrm{mg} \text {; selenium } \\
\text { (Sodium Selenite), } 0.3 \mathrm{mg} \text {, vitamin A, 9,600 IU; vitamin } \mathrm{D}_{3} 3,600 \mathrm{IU} \text {; } \\
\text { vitamin E, } 18 \mathrm{mg} \text {; vitamin } \mathrm{B}_{12}, 15 \mathrm{mcg} \text {; riboflavin, } 10 \mathrm{mg} \text {; niacin, } 48 \mathrm{mg} \text {; } \\
\text { d-pantothenic acid, } 18 \mathrm{mg} \text {; vitamin } \mathrm{K}, 2 \mathrm{mg} \text {; folic acid, } 1.2 \mathrm{mg} \text {; vitamin } \\
\mathrm{B}_{6}, 4 \mathrm{mg} \text {; thiamine, } 3 \mathrm{mg} \text {; d-biotin, } 72 \mathrm{mcg} .{ }^{4} \text { Non-starch polysaccharides. }\end{array}$} \\
\hline
\end{tabular}

\section{RESULTS}

Average body weights were 47, 121 and $260 \mathrm{~g}$ at hatch, 4 and 9 days of age, respectively, which is close to the expected weight of the genetic line (Cobb-Vantress Inc., 2015) and no differences were observed between treatments. A detailed description of results has previously been published (Santos et al., 2019).
Claudin, occludin and interleukin 2 gene expression

Gene expression for claudin 1 and claudin 5, occludin and interleukin 2 was reduced $(\mathrm{p}<0.001)$ at 9 days compared to hatch and 4 days of age (Table 3 ). At 4 days of age, inclusion of 1 and $3 \mathrm{~kg} /$ tonne of betaine reduced $(p<0.05)$ gene expression of claudin 5 and occludin while inclusion of $5 \mathrm{~kg} /$ tonne had intermediate results (Table 4). At day 9, reduction was dependent on the fibre content in the diet as betaine inclusion reduced $(\mathrm{p}$ $<0.0001$ ) claudin 1 and 5, occludin and interleukin 2 gene expression in the low fibre diets but no effect was observed in high fibre diets. When betaine was not included in the diet, broilers fed the high fibre diets also presented lower $(\mathrm{p}<0.0001)$ gene expression for claudin 1 and 5, occludin and interleukin 2 (Table 4).

\section{Peripheral blood mononuclear cells}

Peripheral blood mononuclear cells population varied depending on the age and inclusion of betaine, while fibre concentration had no effect. The population of CD8-CD28+ and CD8+CD28+ cells increased ( $p$ < 0.0001 ) from hatch to 4 days of age and fell thereafter, while CD8+CD28- cells further increased $(\mathrm{p}<0.0001)$ at day 9 (Table 5). Betaine inclusion increased $(\mathrm{p}<0.0001)$ the proportion of both CD8-CD28+ and CD8+CD28+ cells independent of the dose and age, but had no effect on the population of CD8+CD28- cells (Table 5). On the other hand, the proportion of CD4+TCRv $\beta 1+$ and CD4+TCRv $\beta 1$ - cells increased $(\mathrm{p}<0.0001)$ from hatch to 4 days of age and fell afterwards, whilst CD4-TCRv $\beta 1+$ increased $(\mathrm{p}<0.0001)$ from hatch to 4 days and 4 to 9 days of age (Table 5). The impact of betaine on the proportion of CD4+TCRv $\beta 1+$; CD4+TCRv $\beta 1$ - and CD4TCRv $\beta 1+$ populations depended upon age (Table 6$)$. At 4 days of age, inclusion of $3 \mathrm{~kg} /$ tonne of betaine increased ( $\mathrm{p}$ $<0.0001$ ) the proportion of CD4-TCRv $\beta 1+$; and inclusion of $5 \mathrm{~kg} /$ tonne increased $(\mathrm{p}<0.0001)$ the proportion of both CD4+TCRv $\beta 1+$ and CD4+TCRv $\beta 1$ - cells, but no effect of betaine inclusion was observed at 9 days of age. The proportion of both Mo+MHCII+ and Mo-MHCII+ cells compared with total cells increased $(\mathrm{p}<0.0001)$ in birds at 4 days of age while that of Mo+MHCII- fell $(\mathrm{p}<0.0001)$ between 4 and 9 days of age (Table 5). Age affected the $\mathrm{CD} 4: \mathrm{CD} 8$ ratio with the $\mathrm{CD} 4+\mathrm{CD} 8+$ ratio falling ( $\mathrm{p}$ $<0.001$ ) between days 4 and 9 , but no difference was observed between these ages and birds at hatch. 
Table 2. Primers used for real-time PCR

\begin{tabular}{lccc}
\hline Genes & Forward primer sequence (5'-3') & Reverse primer sequence (5'-3') & $\begin{array}{c}\text { Fragment size (base } \\
\text { pair) }\end{array}$ \\
\hline$G A P D H^{1}$ & TCTGGAGAAACCAGCCAAGT & GAGACAACCTGGTCCTCTGTG & 104 \\
$C L D N 1^{2}$ & CCAATGAAGAGGGCTGAT & GTGCATGGAGGATGACCA & 185 \\
$I L 2^{3}$ & TCCCAGGTAACACTGCAGAGTTT & TTGGAAAATATCAAGAACAAGATTCATC & 92 \\
$C L D N 5^{4}$ & ATCTGTGCGCCTTTGAGACT & GCGACCTGCAATGAGTTCG & 149 \\
$O C L N^{5}$ & GTGGGTTCCTCATCGTCATC & GTTCTTCACCCACTCCTCC & 156 \\
\hline
\end{tabular}

${ }^{1}$ Glyceraldehyde 3-phosphate dehydrogenase; ${ }^{2}$ Claudin $1 ;{ }^{3}$ Interleucine $2 ;{ }^{4}$ Claudin $5 ;{ }^{5}$ Occludin

Table 3. Claudin 1, Claudin 5, Occludin and Interleukin 2 gene expression (log of the proportion of GADPH expression) on jejunal samples of broilers at hatch, 4 and 9 days of age. ${ }^{1}$

\begin{tabular}{|c|c|c|c|c|}
\hline Age (days) & Claudin 1 & Claudin 5 & Occludin & Interleukin 2 \\
\hline hatch & $-0.055^{\mathrm{a}}$ & $-0.588^{\mathrm{a}}$ & $-0.176^{\mathrm{a}}$ & $-0.798^{\mathrm{a}}$ \\
\hline 4 & $-0.374^{\mathrm{a}}$ & $-0.687^{\mathrm{a}}$ & $-0.469^{\mathrm{a}}$ & $-0.108^{\mathrm{a}}$ \\
\hline 9 & $-2.828^{b}$ & $-2.521^{b}$ & $-2.143^{b}$ & $-2.184^{b}$ \\
\hline SEM & 0.109 & 0.211 & 0.137 & 0.202 \\
\hline $\mathrm{p}$-value & $<0.001$ & $<0.001$ & $<0.001$ & $<0.001$ \\
\hline
\end{tabular}

${ }^{\mathrm{T}}$ Means and standard error of the mean (SEM) represent 10 birds at hatch, 4 and 9 days of age. ${ }^{\mathrm{a}, \mathrm{b}}$ Mean within columns with different superscripts are statistically different $(\mathrm{p}<0.05)$.

Table 4. Claudin 1, Claudin 5, Occludin and Interleukin 2 gene expression (log of the proportion of GADPH expression) on jejunal samples of broilers at 4 and 9 days of age and fed diets with different fibre concentration and betaine inclusion. ${ }^{1}$

\begin{tabular}{|c|c|c|c|c|c|c|c|c|c|}
\hline \multirow{3}{*}{ Treatment } & & \multicolumn{2}{|c|}{ Claudin 1} & \multicolumn{2}{|c|}{ Claudin 5} & \multicolumn{2}{|c|}{ Occludin } & \multicolumn{2}{|c|}{ Interleukin 2} \\
\hline & & \multirow[b]{2}{*}{4} & \multirow[b]{2}{*}{9} & \multirow[b]{2}{*}{4} & \multicolumn{2}{|c|}{ Age (days) } & \multirow[b]{2}{*}{9} & \multirow[b]{2}{*}{4} & \multirow[b]{2}{*}{9} \\
\hline & & & & & 9 & 4 & & & \\
\hline \multicolumn{10}{|l|}{ Fibre } \\
\hline Low $^{2}$ & & -0.145 & -1.820 & -1.008 & -2.081 & -0.918 & -1.591 & -0.482 & -3.087 \\
\hline $\operatorname{High}^{3}$ & & -0.136 & -2.526 & -0.734 & -2.768 & -0.605 & -2.143 & -0.472 & -3.769 \\
\hline SEM & & 0.095 & 0.125 & 0.147 & 0.145 & 0.143 & 0.117 & 0.098 & 0.142 \\
\hline \multicolumn{10}{|c|}{ Betaine (kg/tonne) } \\
\hline 0 & & -0.001 & -1.277 & $-0.359^{\mathrm{a}}$ & -1.680 & $-0.237^{\mathrm{a}}$ & -1.354 & -0.356 & -2.255 \\
\hline 1 & & -0.228 & -2.279 & $-1.161^{\mathrm{b}}$ & -2.780 & $-1.095^{\mathrm{b}}$ & -2.021 & -0.500 & -3.672 \\
\hline 3 & & -0.182 & -2.678 & $-1.183^{\mathrm{b}}$ & -2.632 & $-1.050^{\mathrm{b}}$ & -1.918 & -0.504 & -4.005 \\
\hline 5 & & -0.153 & -2.432 & $-0.774^{\mathrm{ab}}$ & -2.660 & $-0.660^{\mathrm{ab}}$ & -2.071 & -0.549 & -3.781 \\
\hline SEM & & 0.135 & 0.178 & 0.208 & 0.204 & 0.203 & 0.166 & 0.139 & 0.203 \\
\hline \multicolumn{10}{|c|}{ Fibre $\times$ Betaine(kg/tonne) } \\
\hline \multirow[t]{4}{*}{ Low } & 0 & & $-0.134^{\mathrm{a}}$ & & $-0.426^{\mathrm{a}}$ & & $-0.304^{\mathrm{a}}$ & & $-0.874^{a}$ \\
\hline & 1 & & $-1.886^{\mathrm{b}}$ & & $-2.455^{\mathrm{b}}$ & & $-1.723^{b c}$ & & $-3.218^{\mathrm{b}}$ \\
\hline & 3 & & $-2.854^{\mathrm{b}}$ & & $-2.618^{\mathrm{b}}$ & & $-1.990^{\mathrm{bc}}$ & & $-4.160^{\mathrm{b}}$ \\
\hline & 5 & & $-2.611^{b}$ & & $-2.932^{\mathrm{b}}$ & & $-2.426^{\mathrm{bc}}$ & & $-4.097^{\mathrm{b}}$ \\
\hline \multirow[t]{4}{*}{ High } & 0 & & $-2.548^{\mathrm{b}}$ & & $-2.934^{\mathrm{b}}$ & & $-2.666^{c}$ & & $-3.635^{\mathrm{b}}$ \\
\hline & 1 & & $-2.934^{\mathrm{b}}$ & & $-3.105^{\mathrm{b}}$ & & $-2.518^{\mathrm{bc}}$ & & $-4.126^{\mathrm{b}}$ \\
\hline & 3 & & $-2.502^{\mathrm{b}}$ & & $-2.646^{\mathrm{b}}$ & & $-1.846^{\mathrm{bc}}$ & & $-3.850^{\mathrm{b}}$ \\
\hline & 5 & & $-2.176^{\mathrm{b}}$ & & $-2.388^{b}$ & & $-1.564^{\mathrm{bc}}$ & & $-3.466^{\mathrm{b}}$ \\
\hline SEM & & & 0.229 & & 0.293 & & 0.238 & & 0.291 \\
\hline \multicolumn{10}{|l|}{ p-value } \\
\hline Fibre & & 0.928 & 0.001 & 0.167 & 0.002 & 0.111 & 0.002 & 0.940 & 0.001 \\
\hline Betain & & 0.658 & $<0.001$ & 0.021 & 0.001 & 0.013 & 0.046 & 0.776 & $<0.001$ \\
\hline Fibre $x$ & aine & 0.388 & $<0.001$ & 0.945 & $<0.001$ & 0.866 & $<0.001$ & 0.604 & $<0.001$ \\
\hline
\end{tabular}

${ }^{\mathrm{T}}$ Means and standard error of the mean represent 10 birds/treatment at 4 and 9 days of age. ${ }^{2}$ Corn-soybean meal diet. ${ }^{3}$ Corn-rice bran-soybean meal diet. ${ }^{\text {a-c }}$ Mean within columns with different superscripts are different $(\mathrm{p}<0.05)$. 
Table 5. Leukocyte population determined by flow cytometry (log of the proportion of the population) on blood samples of broilers fed diets with different fibre concentration and betaine inclusion at hatch, 4 and 9 days of age. ${ }^{1}$

\begin{tabular}{|c|c|c|c|c|c|c|c|c|c|c|}
\hline Leukocytes & $\begin{array}{c}\text { CD8- } \\
\text { CD28+ }\end{array}$ & $\begin{array}{c}\text { CD8+ } \\
\text { CD28+ }\end{array}$ & $\begin{array}{l}\text { CD8+ } \\
\text { CD28- }\end{array}$ & $\begin{array}{c}\text { Mo+ } \\
\text { MHCII- }\end{array}$ & $\begin{array}{c}\text { Mo+ } \\
\text { MHCII+ }\end{array}$ & $\begin{array}{c}\text { Mo- } \\
\text { MHCII+ }\end{array}$ & $\begin{array}{c}\text { CD4- } \\
\text { TCRvß1+ }\end{array}$ & $\begin{array}{c}\text { CD4+ } \\
\text { TCRvß1+ }\end{array}$ & $\begin{array}{c}\text { CD4+ } \\
\text { TCRvß1- }\end{array}$ & $\begin{array}{c}\text { CD4:CD8 } \\
\text { Ratio }\end{array}$ \\
\hline \multicolumn{11}{|l|}{$\overline{\text { Age (days) }}$} \\
\hline hatch & $0.553^{\mathrm{b}}$ & $0.012^{\mathrm{c}}$ & $-1.425^{\mathrm{c}}$ & $-0.496^{\mathrm{a}}$ & $0.044^{\mathrm{b}}$ & $-0.266^{\mathrm{b}}$ & $-0.375^{\mathrm{c}}$ & $0.360^{\mathrm{c}}$ & $-0.128^{\mathrm{c}}$ & $2.91^{\mathrm{ab}}$ \\
\hline 4 & $1.141^{\mathrm{a}}$ & $0.603^{\mathrm{a}}$ & $-0.399^{\mathrm{b}}$ & $-0.457^{\mathrm{a}}$ & $0.476^{\mathrm{a}}$ & $0.028^{\mathrm{a}}$ & $0.286^{\mathrm{b}}$ & $0.959^{\mathrm{a}}$ & $0.568^{\mathrm{a}}$ & $3.15^{\mathrm{a}}$ \\
\hline 9 & $0.726^{\mathrm{b}}$ & $0.276^{\mathrm{b}}$ & $0.106^{\mathrm{a}}$ & $-0.839^{\mathrm{b}}$ & $0.430^{\mathrm{a}}$ & $0.007^{\mathrm{a}}$ & $0.382^{\mathrm{a}}$ & $0.563^{\mathrm{b}}$ & $0.307^{\mathrm{b}}$ & $2.01^{\mathrm{b}}$ \\
\hline SEM & 0.028 & 0.029 & 0.031 & 0.053 & 0.032 & 0.034 & 0.028 & 0.028 & 0.031 & 0.15 \\
\hline \multicolumn{11}{|l|}{ Fibre } \\
\hline Low $^{2}$ & 0.930 & 0.445 & -0.139 & -0.647 & 0.469 & 0.045 & 0.366 & 0.774 & 0.415 & 2.60 \\
\hline $\mathrm{High}^{3}$ & 0.902 & 0.437 & -0.111 & -0.682 & 0.432 & -0.015 & 0.308 & 0.756 & 0.443 & 2.49 \\
\hline SEM & 0.026 & 0.027 & 0.031 & 0.052 & 0.031 & 0.033 & 0.026 & 0.027 & 0.029 & 0.14 \\
\hline \multicolumn{11}{|l|}{ Betaine (kg/tonne) } \\
\hline 0 & $0.824^{\mathrm{b}}$ & $0.286^{\mathrm{b}}$ & -0.224 & -0.801 & 0.431 & -0.043 & 0.259 & 0.690 & 0.339 & 2.84 \\
\hline 1 & $0.971^{\mathrm{a}}$ & $0.495^{\mathrm{a}}$ & -0.164 & -0.660 & 0.497 & 0.028 & 0.370 & 0.773 & 0.436 & 2.35 \\
\hline 3 & $0.977^{\mathrm{a}}$ & $0.466^{\mathrm{a}}$ & -0.079 & -0.602 & 0.475 & 0.042 & 0.318 & 0.774 & 0.465 & 2.48 \\
\hline 5 & $0.964^{\mathrm{a}}$ & $0.516^{\mathrm{a}}$ & -0.112 & -0.537 & 0.404 & 0.039 & 0.384 & 0.823 & 0.515 & 2.50 \\
\hline SEM & 0.037 & 0.037 & 0.044 & 0.073 & 0.043 & 0.046 & 0.036 & 0.038 & 0.041 & 0.21 \\
\hline \multicolumn{11}{|l|}{ p-value } \\
\hline Age & $<0.001$ & $<0.001$ & $<0.001$ & $<0.001$ & $<0.001$ & $<0.010$ & $<0.001$ & $<0.001$ & $<0.001$ & $<0.001$ \\
\hline Fibre & 0.719 & 0.822 & 0.727 & 0.560 & 0.356 & 0.172 & 0.120 & 0.629 & 0.457 & 0.489 \\
\hline Betaine & 0.010 & $<0.001$ & 0.107 & 0.082 & 0.435 & 0.536 & 0.074 & 0.107 & 0.027 & 0.423 \\
\hline Fibre $\times$ Betaine & 0.949 & 0.497 & 0.561 & 0.162 & 0.058 & 0.224 & 0.318 & 0.852 & 0.985 & 0.385 \\
\hline Fibre $\times$ Age & 0.402 & 0.849 & 0.428 & 0.188 & 0.519 & 0.903 & 0.632 & 0.413 & 0.478 & 0.437 \\
\hline Age $\times$ Betaine & 0.118 & 0.377 & 0.545 & 0.393 & 0.125 & 0.191 & 0.011 & 0.050 & 0.036 & 0.216 \\
\hline Fibre $\times$ Age $\times$ Betaine & 0.671 & 0.684 & 0.962 & 0.974 & 0.712 & 0.962 & 0.611 & 0.688 & 0.554 & 0.082 \\
\hline
\end{tabular}

${ }^{\mathrm{T}}$ Means and standard error of the mean represent 10 birds at hatch day of age and 10 birds/treatment at 4 and 9 days of age. ${ }^{2}$ Corn-soybean meal diet. ${ }^{3}$ Corn-rice bransoybean meal diet. ${ }^{a-c}$ Mean within columns with different superscripts are different $(\mathrm{p}<0.05)$.

\section{DISCUSSION}

At hatch, the paracellular junctions between enterocytes in the intestine are not well developed, allowing the paracellular transport of large molecules from the yolk sac. This route of absorption reduces rapidly as these paracellular junctions tighten. The results from the present experiment support this hypothesis as the gene expression for claudin 1 and claudin 5 and occludin was greater between hatch and 4 days compared with birds at day 9 . This suggests a greater rate of production of these proteins to increase the strength of these junctions during the first few days post hatch. The percentage of enterocyte membrane involved in tight junctions increases in the 3 days after hatch (Karcher and Applegate, 2008), supporting that during these early days post hatch, the tight junctions become more rigid.

Gene expression of interleukin 2 tended to increase gene expression between hatch and 4 days and reducing afterwards. Interleukin 2 is a proinflammatory interleukin involved in the proliferation of lymphocytes by stimulating the transition of activated $T$ cells from the $G_{1}$ to the S phase (Han et al., 2010). An increase in interleukin gene expression between hatch and 4 days of age may be related to a transitory proinflammatory status as birds may be reacting to the presence of digesta in the gastrointestinal tract. Most of the materials in the gastrointestinal tract, although not pathogenic, are capable of stimulating an immune response (Huges, 2005).

At hatch the gastrointestinal tract of chickens is empty, with absorption of fat and readily available proteins in the yolk sac taking place majorly from the yolk sac membrane and the intestine directly into the blood (Noy and Sklan, 2001). Once birds hatch and start to consume feed with more complex nutrients (more complex proteins, carbohydrates, fibre, etc), the intestine may react immunologically due to the presence of these nutrients in the lumen. Given at hatch the digestive tract of chicken is not completely developed (Geyra et al., 2001), the low digestibility and absorption rates can result in a hyperosmotic solution that further contributes to a proinflammatory response (Hubert et al., 2004; Schwartz et al., 2009). It is estimated that $3 \%$ of the metabolised energy of the chicken could be directed towards the 
maintenance of a feed-induced immune response (Kogut, 2017).

At 4 days of age, the inclusion of 1 and $3 \mathrm{~kg} /$ tonne of betaine in the diet reduced gene expression for claudin 5 and occludin, which suggests there has been a quicker development of the gastrointestinal tract and the demand for tight junction formation has reduced. Tight junction formation is affected by enterocyte differentiation and replication (Karcher and Applegate, 2008). Betaine inclusion increases villus height, modulates immune response and improves gastrointestinal tract recovery after a coccidial challenge (Kettunen et al., 2001; Klasing et al., 2002). As an osmoprotectant, betaine may help the gastrointestinal tract maintain its physiology when facing a transitory hyperosmotic period. At 9 days of age, gene expression of claudin 1, claudin 5, occludin and interleukin 2 were higher in broilers fed the low fibre diet and these were reduced by both betaine inclusion or fibre addition. Fibre interferes with the inflammatory responses in broilers but it is dependent upon the type of fibre used (Teirlynck et al., 2009). Inclusion of soluble fibre increases inflammatory responses while insoluble fibre reduce these inflammatory responses and stimulate villus growth (Rezaei et al., 2011; Adedokun et al., 2012). Fibre composition in rice bran is mainly represented by insoluble fibre.

Cytotoxic $\mathrm{T}$ cells are classified dependent on the presence of CD8 and CD28 in the superficia of their membrane. $\mathrm{T}$ cells that express both CD8 and CD28 are recognised as $\mathrm{T}$ cells in initial stages of activation or memory cells $(\mathrm{CD} 8+\mathrm{CD} 28+)$ and $\mathrm{T}$ cells that express CD28 but not CD8 are recognised as non-activated T cells (CD8-CD28+) (Nabeshima et al., 2002). When T cells are activated for a long period of time, they lose the expression of CD28 while maintaining CD8 expression and are classified as activated cytotoxic $\mathrm{T}$ cells (CD8+CD28-). These cells are specific to target antigens and cannot replicate (Nabeshima et al., 2002; Pawelec et al., 2004).

The proportion of cytotoxic $\mathrm{T}$ cells in the leukocyte population increased between hatch and 4 days, and a reduction in this percentage was observed for CD8-CD28+ and $\mathrm{CD} 8+\mathrm{CD} 28+$ between 4 and 9 days, while $\mathrm{CD} 8+\mathrm{CD} 28$ - increased further. The initial increase in the population of cytotoxic $\mathrm{T}$ cells may be related to the development of the immune system. Beirão et al. (2012) observed that under normal commercial conditions the levels of cytotoxic $\mathrm{T}$ cells increase in proportion to other $\mathrm{T}$ cells from day of age to 5 weeks This suggests that the changes noted in the present study is related to an early development of the immune system. Betaine inclusion increases the proportion of CD8+CD28+ and CD8-CD28+ suggesting it aids in the development of the immune status but no effect was observed in the population of $\mathrm{CD} 8+\mathrm{CD} 28$ - as the effect of betaine is likely not related to specific antigens.

Helper T cells are classified by the presence of CD4 and TCRv $\beta 1$ phenotypes. Helper T cells with CD4+ and TCRv $\beta 1$ - (CD4+TCRv $\beta 1-)$ reaction are recognised as classical helper $\mathrm{T}$ cells and are responsible for activation of lymphocytes and adaptative immune response (Chan et al., 1988). When TCRv $\beta 1$ is expressed (CD4+ TCRv $\beta 1+$ ) cells tends to migrate to the mucosa where they are responsible for IgA production (Cihak et al., 1991). Other helper $\mathrm{T}$ cell that express $\mathrm{TCRv} \beta 1$, but not $\mathrm{CD} 4$, are classified as cytotoxic mucosal $\mathrm{T}$ cells (CD4- TCRv $\beta 1+)$ and have an important role in cellular immunity (Lillehoj, 1994). Birds challenged by Salmonella spp. have reduced concentrations of CD4 and CD8 in the peripheral blood (Flores et al., 2012) which actually increases their susceptibility to Salmonella infection (Kamalavenkatesh et al., 2005). Inclusion of betaine increased the percentage of helper $T$ cells at 4 days but not at 9 days of age. As the objective of the present study was not to measure the response to a specific pathogen, but to evaluate the immune system development in young birds, it could be concluded that betaine may play a role as an immune modulator during the transition period following hatch and improve immune competence.

Monocytes (Mo+ MHCII+) are precursors of macrophages in different tissues and express Mo marker in the membrane and represents a connection between the innate and adaptative immune responses. There are other cells that are not monocytes (Mo-) that may also be antigen-presenting cells when expressing the MHCII marker in its membrane (Mo-MHCII+). Monocytes that do not present the MHCII marker reduce lymphocyte activity, classified as suppressor monocytes (Mo+MHCII-) (Masternak and Reith, 2002). An increase in the proportion of both Mo+MHCII+ and MO-MHCII+ between hatch and 4 days of age and the reduction of suppressor monocytes (Mo+MHCII-) shows how the chick prepares for any immune response during these early stages. The betaine and fibre concentration in the diet did not affect the proportion of these populations.

The ratio between CD4 and CD8 cells may be used as an indicator of cell-mediated immune response (Cheng et al., 2001). Higher ratios of CD4:CD8 are usually an indication of immunocompetence (Beirão et al., 2012), whilst reduced values are usually associated with 
challenging environmental factors, immunization or challenges such as bronchitis (Beirão et al., 2012). Genetic selection for higher growth and egg production is also associated with a reduction in CD4:CD8 ratio (Cheng et al., 2001). In the present evaluation, the CD4:CD8 ratio was reduced ( $\mathrm{p}<0.001)$ at day 9 compared with day 4 but the results were still greater than 1.5 which is considered as a normal ratio (Cheng et al., 2001) when cellular immune mechanisms are not impaired and survivability is not compromised (Reid and Tervit, 1995; Levinson and Jawetz, 1996). A reduction of the CD4:CD8 ratio can be associated with a natural exposure to immune estimulators in the environment as the ratio is reduced in birds raised commercially compared with birds raised specifically to be pathogen-free (Flores et al., 2012). Some degree of immune challenge may be required to develop the immune system by increasing the relationship between helper and cytotoxic cells (Beirão et al., 2012). Neither fibre concentration nor betaine inclusion affected the CD4:CD8 ratio in the current study. A lack of response may be related to the development of the immune system being a result of exposure to a moderate bacterial challenge, but not a challenge by specific pathogens.

\section{CONCLUSION}

Betaine inclusion reduced expression of claudin 5 and occludin, and increased the proportion of cytotoxic T cells, non-activated helper $\mathrm{T}$ cells, and helper $\mathrm{T}$ cells. These results suggest that betaine can be used as a modulator of immune maturation during the early days post hatch, probably not by acting directly on these immune cells but helping the birds to support and adapt to this initial period and then reducing the inflammatory response associated with this adaptation process. Fibre content had no effect on the gene expression and leukocyte population in broilers until 9 days of age. As fibre will affect the microbiota population in the gut, it is possible that the effect of fibre on the immune status of broilers takes longer to develop. In both cases, the fluctuation of the local gene expression for tight junction proteins and leukocyte populations shows that gut development is closely linked with development of the systemic immune system due to the role of the gut as a sensory organ.

\section{DECLARATIONS}

\section{Authors' contributions}

Tiago Tedeschi dos Santos, Suelen Baal and Ana Vitória Fisher da Silve designed the trial and developed it.
Celso Favero worked on Laboratory analysis. Mike Bedford, Sophie Lee and Tiago Tedeschi dos Santos analysed the statistical data and wrote the article. All authors confirmed the final version of the original article for publishing in this journal.

\section{Competing interests}

All authors declare no conflicts of interest.

\section{REFERENCES}

Adedokun S, Ajuwon K, Romero L and Adeola O (2012). Ileal endogenous amino acid losses. Response of broiler chickens to fibre and mild coccidial vaccine challenge. Poultry Science, 91: 899-907. DOI: https://doi.org/10.3382/ps.2011-01777

Adeola O, Xue PC, Cowieson AJ and Ajuwon KM (2016). Basal endogenous losses of amino acids in protein nutrition research for swine and poultry. Animal Feed Science and Technology, 221: 274-283. DOI: https://doi.org/10.1016/j.anifeedsci.2016.06.004

Ballou A, Ali R, Mendoza M, Ellis J, Hassan H, Croom W and Koci M (2016). Development of the chick microbiome: How early exposure influences future microbial diversity. Frontiers Veterinary Science, 3 : $2 . \quad$ DOI: https://doi.org/10.3389/fvets.2016.00002

Beirão B, Fávaro Jr C, Nakao L, Caron L, Zanata S and Mercadante A (2012). Flow cytometric immune profiling of specific-pathogenfree chickens before and after infectious challenges. Veterinary Immunology and Immunopathology, 145: 32-41. DOI: https://doi.org/10.1016/j.vetimm.2011.10.004

Bridle B, Julian R, Shewen P, Vaillancourt J and Kaushik A (2006). T lymphocyte subpopulations diverge in commercially raised chickens. Canadian Journal of Veterinary Research, 70: 183-190. Available https://www.ncbi.nlm.nih.gov/pmc/articles/PMC1477934/

Bustin S, BenesV, Garson J, Hellemans J, Huggett J, Kubista M, Mueller R, Nolan T, Pfaffl M, Shipley G, Vandesompele J and Wittwer C (2009). The MIQE Guidelines: minimum information for publication of quantitative real-time PCR experiments. Clinic Chemistry, 55: 611-622. DOI: https://doi.org/10.1373/clinchem.2008.112797

Cazaban C, Masferrer N, Pascual R, Espadamala M, Costa T and Gardin Y (2015). Proposed bursa of Fabricius weight to body weight ratio standard in commercial broilers. Poultry Science, 94: 2088-2093. DOI: https://doi.org/10.3382/ps/pev230

Celi P, Cowieson A, Fru-Nji F, Steinert R, Kluenter A and Verlhac V (2017). Gastrointestinal functionality in animal nutrition and health: New opportunities for sustainable animal production. Animal Feed Science and Technology, 234: 88-100. DOI: https://doi.org/10.1016/j.anifeedsci.2017.09.012

Chan M, Chen C, Ager L and Cooper M (1988). Identification of the avian homologues of mammalian CD4 and CD8 antigens. Journal of Immunology, 140: 2133-2138. Available at: https://www.jimmunol.org/content/140/7/2133.long

Cheng H, Eicher S, Chen Y, Singleton P and Muir W (2001). Effect of genetic selection for group productivity and longevity on immunological and hematological parameters of chickens. Poultry Science, $\quad 80: \quad 1079-1086 . \quad$ DOI: https://doi.org/10.1093/ps/80.8.1079

Cihak J, Hoffmann-Fezer G, Ziegler-Heibrock H, Stein H, Kaspers B, Chen C, Cooper M and Losch U (1991). T cells expressing the V beta $1 \mathrm{~T}$-cell receptors are required for $\operatorname{IgA}$ production in the chicken. Proceedings of the National Academy of Sciences of the 
United States of America, 88: 10951-10955. DOI: https://doi.org/10.1073/pnas.88.23.10951

Cobb-Vantress Inc. (2015). Cobb 500 SF Breeder Management and Cobb 500 Broiler performance. Available at: http://www.cobbvantress.com/products/cobb-500

Dibner JJ, Knight CD, Kitchell ML, Atwell CA, Downs AC and Ivey FJ (1998). Early feeding and development of the immune system in neonatal poultry. Journal of Applied Poultry Research, 7: 425-436. DOI: https://doi.org/10.1093/japr/7.4.425

Fair J, Taylor-McCabe K, Shou Y and Marrone B (2008). Immunophenotyping of chicken peripheral blood lymphocyte subpopulations: individual variability and repeatability. Veterinary Immunology and Immunopathology, 125: 268-273. DOI: https://doi.org/10.1016/j.vetimm.2008.05.012

Flores F, Lovato M, Wilsmann C, Gazoni F, Silveira F, Caron L and Beirão B (2012). Comportamento de células do Sistema immune frente ao desafio dom Salmonella Enteritidis em aves tratadas e não tratadas com ácidos orgânicos. Pesquisa Veterinária Brasileira, 32: 495-502. DOI: http://dx.doi.org/10.1590/S0100736X2012000600005

Furness J, Rivera L, Cho H, Bravo D and Callaghan B (2013). The gut as a sensory organ. National Review of Gastroenterology and Hepatology, $\quad 10: \quad 729-740 . \quad$ DOI: https://doi.org/10.1038/nrgastro.2013.180

Geyra A, Uni Z and Sklan D (2001). Enterocyte dynamics and mucosal development in the posthatch chick. Poultry Science, 80: 776-782. DOI: https://doi.org/10.1093/ps/80.6.776

Han A, Zhang M, Zuo X, Zheng S, Zhao C, Feng J and Cheng C (2010). Effect of acute heat stress on calcium concentration, proliferation, cell cycle, and interleukin-2 production in splenic lymphocytes from broiler chickens. Poultry Science, 89: 2063-2070. DOI: https://doi.org/10.3382/ps.2010-00715

Hubert A, Cauliez B, Chedeville A, Husson A and Lavoinne A (2004). Osmotic stress, a proinflammatory signal in Caco-2 cells. Biochimie, 86: 533-541. DOI: https://doi.org/10.1016/j.biochi.2004.07.009

Huges R (2005). An integrated approach to understand gut function and gut health of chickens. Asian Pacific Journal of Clinical Nutrition, 14: S27. Available at: https://search.proquest.com/openview/7466dda609e3b5accca7775 $\underline{\mathrm{f} 27 \mathrm{dc} 4591 / 1 \text { ?pq-origsite }=\text { gscholar } \& \mathrm{cbl}=45812}$

Kamalavenkatesh P, Vairamuthu S, Balachandran C, Murali-Manohar B and Dhinakar-Raj G (2005). Immunopathological effect of the mycotoxins cyclopiazonic acid and T-2 toxin on broiler chicken. $\begin{array}{lll}\text { Mycopathologia, } & \text { 159: } & \text { 273-279. }\end{array}$ https://doi.org/10.1007/s11046-004-7321-0

Karcher D and Applegate T (2008). Survey of enterocyte morphology and tight junction formation in the small intestine of avian embryos. Poultry Science, 87: 339-350. DOI: https://doi.org/10.3382/ps.2007-00342

Kettunen H, Tiihonen K, Peuranen S, Saarinen MT and Remus JC (2001). Dietary betaine accumulates in the liver and intestinal tissue and stabilizes the intestinal epithelial structure in healthy and coccidian-infected broiler chicks. Compendium of Biochemistry and Physiology, 130: 759-769. DOI: https://doi.org/10.1016/S1095-6433(01)00410-X

Klasing KC, Adler KL, Remus JC and Calvert CC (2002). Dietary betaine increased intraepithelial lymphocytes in the duodenum of coccidian-infected chicks and increases functional properties of phagocytes. Journal of Nutrition, 132: 2274-2282. DOI: https://doi.org/10.1093/jn/132.8.2274

Kogut M (2017). Issues and consequences of using nutrition to modulate the avian immune response. Journal of Applied Poultry Research, 26: 605-612. DOI: https://doi.org/10.3382/japr/pfx028
Levinson W and Jawetz E (1996). Medical microbiology and immunology. Appleton and Lance, Stamford.

Lillehoj H (1994). Analysis of Eimeria acervulina-induced changes in the intestinal lymphocyte subpopulations in two chickens strains showing different levels of susceptibility to coccidiosis. Research on Veterinary Science, 56: 1-7. DOI: https://doi.org/10.1016/0034-5288(94)90188-0

Masternak K and Reith W (2002). Promoter-specific functions of CIITA and the MHC class II enhanceosome in transcriptional activation. EMBO Journal, 21: 1379-1388. DOI: https://doi.org/10.1093/emboj/21.6.1379

Matthews JO and Southern LL (2000). The effect of dietary betaine in Eimeria acervulina-infected chicks. Poultry Science, 79: 60-65. DOI: https://doi.org/10.1093/ps/79.1.60

Nabeshima S, Murata M, Kikuchi K, Ikematsu H, Kashiwagi S and Hayashi J (2002). A reduction in the number of peripheral $\mathrm{CD} 28+\mathrm{CD} 8+\mathrm{T}$ cells in the acute phase of influenza. Clinical Experimental Immunology, 128: 339-346. DOI: https://doi.org/10.1046/j.1365-2249.2002.01819.x

Noy Y and Sklan D (2001). Yolk and exogenous feed utilization in the posthatch chick. Poultry Science, 80: 1490-1495. DOI: https://doi.org/10.1093/ps/80.10.1490

Oakley B and Kogut M (2016). Spatial and temporal changes in the broiler cecal and fecal microbiomes and correlations of bacterial taxa with cytokine gene expression. Frontier Veterinary Science, 3: 11. DOI: https://doi.org/10.3389/fvets.2016.00011

Pawelec G, Akbar A, Caruso C, Effros R, Grubeck-Loebenstein B and Wikby A (2004). Is immunosenescence infectious? Trends in Immunology, 25: 406-410. https://doi.org/10.1016/j.it.2004.05.006

Rahmatnejad E and Saki EE (2016). Effect of dietary fibres on small intestine histomorphology and lipid metabolism in young broiler chickens. Journal of Animal Physiology and Animal Nutrition, 100: 665-672. DOI: https://doi.org/10.1111/jpn.12422

Reid G and Tervit H (1995). Sudden infant death syndrome (SIDS): immunoglobulins and hypoxia. Medical Hypotheses, 44: 202-206. DOI: https://doi.org/10.1016/0306-9877(95)90136-1

Rezaei M, Karimi A, Torshizi MA and Rouzbehan Y (2011). The influence of different levels of micronized insoluble fibre on broiler performance and litter moisture. Poultry Science, 90: 20082012. DOI:https://doi.org/10.3382/ps.2011-01352

Santos TT, Dassi S, Franco, C, Costa C, Lee S and da Silva, A (2019). Influence of fibre and betaine on the development of the gastrointestinal tract of broilers between hatch and 14 days of age. Animal Nutrition, 5: 163-173. DOI: https://doi.org/10.1016/j.aninu.2018.06.005

Schwahn BC, Hafner D, Hohlfeld T, Balkenhol N, Laryea M and Wendel U (2003). Pharmacokinetics of oral betaine in healthy subjects and patients with homocystinuria. Brazilian Journal of Clinical Pharmacology, 55: 6-13. DOI: https://doi.org/10.1046/j.13652125.2003.01717.x

Schwartz L, Guais A, Pooya M and Abolhassani M (2009). Is inflammation a consequence of extracellular hyperosmolarity? Journal of Inflammation, 6: $21 . \quad$ DOI: https://doi.org/10.1186/1476-9255-6-21

Sommer F and Backhed F (2013). The gut microbiota - master of host development and physiology. National Review on Microbiology, 11: 227-238. DOI: https://doi.org/10.1038/nrmicro2974

Stabel T, Bolin S, Pesch B and Rahner T (2000). A simple and rapid flow cytometric method for detection of porcine cell surface markers. Journal of Immunology Methods, 245: 147-52. DOI: https://doi.org/10.1016/S0022-1759(00)00289-1 
Tada T (1997). The immune system as a supersystem. Annual Review of Immunology, 15: $1-13$.

DOI: https://doi.org/10.1146/annurev.immunol.15.1.1

Teirlynck E, Bjerrum L, Eeckhaut V, Huygebaertm G, Pasmans F, Haesebrouck F, Dewulf J, Ducatelle R and Van Immerseel F (2009). The cereal type in feed influences gut wall morphology and intestinal immune cell infiltration in broiler chickens. Brazilian Journal of Nutrition, 102: 1453-1461. DOI: https://doi.org/10.1017/S0007114509990407
Uni Z, Tako E, Gal-Garber O and Sklan D (2003). Morphological, molecular and functional changes in the chicken small intestine of the late-term embryo. Poultry Science, 82: 1747-1754. DOI: https://doi.org/10.1093/ps/82.11.1747

Yegani M and Korver D (2008). Factors affecting intestinal health in poultry. Poultry Science, 87: 2052-2063. DOI: https://doi.org/10.3382/ps.2008-00091 